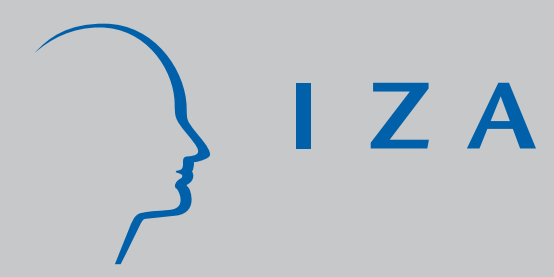

IZA DP No. 789

Recruitment and Pay at the Establishment

Level: Gender Segregation and the Wage

Gap in Portugal

J osé A. Cabral Vieira

Ana Rute Cardoso

Miguel Portela

J une 2003 


\title{
Recruitment and Pay at the Establishment Level: Gender Segregation and the Wage Gap in Portugal
}

\author{
José A. Cabral Vieira
}

University of the Azores

Ana Rute Cardoso

IZA Bonn, University of Minho and CEPR

Miguel Portela

Tinbergen Institute and University of Minho

\author{
Discussion Paper No. 789 \\ June 2003
}

\author{
IZA \\ P.O. Box 7240 \\ D-53072 Bonn \\ Germany \\ Tel.: +49-228-3894-0 \\ Fax: +49-228-3894-210 \\ Email: iza@iza.org
}

This Discussion Paper is issued within the framework of IZA's research area The Future of Labor. Any opinions expressed here are those of the author(s) and not those of the institute. Research disseminated by IZA may include views on policy, but the institute itself takes no institutional policy positions.

The Institute for the Study of Labor (IZA) in Bonn is a local and virtual international research center and a place of communication between science, politics and business. IZA is an independent, nonprofit limited liability company (Gesellschaft mit beschränkter Haftung) supported by the Deutsche Post AG. The center is associated with the University of Bonn and offers a stimulating research environment through its research networks, research support, and visitors and doctoral programs. IZA engages in (i) original and internationally competitive research in all fields of labor economics, (ii) development of policy concepts, and (iii) dissemination of research results and concepts to the interested public. The current research program deals with (1) mobility and flexibility of labor, (2) internationalization of labor markets, (3) welfare state and labor market, (4) labor markets in transition countries, (5) the future of labor, (6) evaluation of labor market policies and projects and (7) general labor economics.

IZA Discussion Papers often represent preliminary work and are circulated to encourage discussion. Citation of such a paper should account for its provisional character. A revised version may be available on the IZA website (www.iza.org) or directly from the author. 
IZA Discussion Paper No. 789

June 2003

\section{ABSTRACT \\ Recruitment and Pay at the Establishment Level: Gender Segregation and the Wage Gap in Portugal*}

This paper aims at quantifying the trend in worker segregation at the establishment level and its impact on wages in Portugal over a fifteen year period. We concentrate on the gender dimension, to answer the questions: have changes in recruitment policies at the establishment level resulted in higher gender segregation in the labour market? What is the impact of segregation on wages? Is that impact different for men and women? A large linked employer-employee data set is used. Systematic and random components of segregation are computed. We use standard wage decomposition techniques to evaluate the impact of the composition of the labour force at the establishment level on wages. Results reveal a high degree of systematic gender segregation. A higher proportion of females in the establishment lowers females' wages while, on the contrary, it raises males' wages. Between mid-80s and late-90s, the contribution of the gender composition of the workforce within the establishment to the wage gap increased, though fluctuating within that period. The evidence gathered lends support to the taste-based model of employer behaviour.

JEL Classification: J31, D21, J7

Keywords: $\quad$ systematic segregation, random segregation, gender, wage inequality

Corresponding author:

Ana Rute Cardoso

IZA

P.O.Box 7240

53072 Bonn

Germany

Tel.: +492283894508

Fax: +492283894180

E-mail: cardoso@iza.org

\footnotetext{
* This research was supported by Fundação para a Ciência e a Tecnologia under the grants $\mathrm{POCTI/ECO/33089/99}$ and, for the third author, SFRH/BD/5114/2001. We are grateful to the Ministry of Employment, Department of Statistics, for access to the dataset used in the paper. The usual disclaimer applies.
} 


\section{Introduction}

The composition of the labour force differs widely across employers. Two main lines of reasoning have been followed to explain that pattern: taste-based or quality-sorting recruitment. In the first case, preferences by employers (or coworkers or customers) will lead an employer into recruiting particular types of workers, but not others. Becker (1971) has set the stage for this analysis, under the heading discrimination in the labour market. The other line of reasoning distinguishes workers by their quality or productivity, to stress sorting effects, according to which similar workers will be matched together in firms, if their skills are complements in the production process. A good version of this type of models is presented in Kremer (1993). Both theories predict that workers with different attributes will be segregated into different workplaces.

Employment segregation will be a source of wage differentials between groups of workers, to the extent that different firms pay different wages. The two theories mentioned diverge, however, on the implications of segregation for wage setting. Nevertheless, while gender segregation along occupation or industry lines has been subject to wide scrutiny, less attention has been devoted to the impact of interemployer gender segregation on wages. Studies evaluating the impact of the degree of femaleness of the establishment on the wages paid have in general found that inter-establishment gender segregation accounts for a substantial share of the wage gap (see Carrington and Troske (1995, 1998), Yoon et al (2003), Reilly and Wirjanto (1999), Groshen (1991), Pfeffer and Davis-Blake (1987) and, for earlier awareness on this pattern, McNulty (1967) and Buckley (1971)).

This paper aims at quantifying the trend in worker segregation across establishments and its impact on wages in Portugal over a fifteen year period. We concentrate on the gender dimension, to answer the questions: have changes in recruitment policies at the establishment level resulted in higher gender segregation in the labour market? What was the impact of segregation on the wages paid? Is that impact different for men and women and, if so, does it lend support to the 
taste-based or the quality-sorting model?

The aim is also to contribute to a better understanding of the Portuguese gender wage gap, which revealed a hump-shaped pattern from 1985 to 1999, reaching a peak in 1991.

The study relies on a large linked employer-employee data set gathered by the Ministry of Employment, based on an inquiry that every establishment with wageearners is legally obliged to fill in. Each year, around two million workers and 200 thousand establishments are covered. Data on the worker include age, tenure with the current firm, schooling, gender, occupation, monthly wages and hours worked. Information on the firm and the establishment include their size, industry and region. Whereas public administration and domestic service are not covered and the coverage of agriculture is low, for manufacturing and the services private sector, the inquiry is in fact a census of the Portuguese economy. The legal request for the data to be permanently displayed in a public space in the establishment contributes to its reliability, and it should reduce measurement errors.

We evaluate worker segregation across establishments as departures from the segregation that would prevail if workers were randomly assigned to establishments, instead of departures from perfect integration, if groups were proportionately represented in each establishment. In fact, Carrington and Troske (1997) have proven that, in particular in the presence of small units, different groups of workers will never be evenly distributed across establishments, even if the allocation is determined on a random basis. We therefore compute random and systematic segregation, using both the Gini and the dissimilarity indeces.

The impact of the degree of femaleness of the establishment on wages will be quantified using the Oaxaca and Cotton-Neumark procedures for wage decomposition.

The paper is organised as follows. Section 2 briefly presents trends in female employment in Portugal. Section 3 analyses systematic gender segregation across establishments. Section 4 discusses the impact of gender segregation on wages, whereas concluding comments are presented in section 5 . 


\section{Trends in female employment in Portugal}

Female employment has been steadily increasing in the Portuguese economy. Whereas it accounted for $32 \%$ of total employment in manufacturing and the services in 1985, by 1999 it had risen to 43\%. The composition of female employment underwent changes as well. The share of employed women holding a University diploma increased during that period from $3 \%$ to $9 \%$, while the share holding a High-School diploma increased from $11 \%$ to $19 \%$. Changes in the composition of male employment have been slower, since those values were, respectively, 4\%, 7\%, $11 \%$ and $16 \%$.

Raw data points to a certain degree of gender segregation at the establishment level (see tables 4 and 5 in appendix). While in the sample of females the average share of women in the establishment is $56 \%$ to $65 \%$, in the sample of males the values range from $20 \%$ to $25 \%$ - females tend to have predominantly female coworkers, and males tend to have predominantly male co-workers.

Economic growth and increasing integration of women into the labour market did not lead in Portugal to a systematic decline in the gender pay gap. In fact, the gap measured as the difference between the mean values of log-wages in each group increased from 1985 to 1991, to decline afterwards. Furthermore, empirical evidence has shown that even after controlling for several worker and employer attributes, the Portuguese wage gap is significant and persistent (Kiker and Santos (1991), Vieira (1999)).

\section{Gender segregation at the establishment level: system- atic and random components}

To evaluate total segregation in the labour force, the Gini and the dissimilarity indeces, respectively $G$ and $D$, have been used (see Hutchens (2001) for a discussion 
of their properties). ${ }^{1}$

$$
D=\sum_{i=1}^{T} \frac{1}{2}\left|w_{i}-m_{i}\right|
$$

where $w_{i}$ and $m_{i}$ are the establishment $i$ 's share of female and male employees in the sample, respectively, and $T$ is the number of establishments in the sample.

$$
G=1-\sum_{i=1}^{T} w_{i}\left(m_{i}+2 \sum_{j=i+1}^{T} m_{j}\right)
$$

with the calculation being performed in the data sorted by $w_{i} / m_{i}$. Both indices are bounded between 0 and 1, with 0 corresponding to maximum evenness (perfect integration), and 1 to maximum unevenness.

However, segregation will never reach the value 0, in particular if the economy is made up of small units, even if workers are randomly allocated to establishments, as proven by Carrington and Troske (1997). One should therefore quantify the degree of systematic segregation existing in the sample, evaluated as departures from random segregation (the one that would result from pure chance in the allocation of workers to establishments), instead of departures from absolute evenness.

To compute random segregation, we consider the original number of females and males and the original establishment size in the sample. Then, workers are randomly reallocated to establishments and the segregation indeces are computed ${ }^{2}$. After 100 replications of this procedure, the average segregation index reached is the random segregation. To obtain the standard errors of the indeces (total, random and systematic), we use a bootstrap technique as in Carrington and Troske $(1998)^{3}$.

The systematic Gini segregation coefficient is computed as follows (Carrington and Troske (1997)):

$$
\hat{G}=\left\{\begin{array}{l}
\frac{G-G^{*}}{1-G^{*}} \text { if } G \geq G^{*} \\
\frac{G-G^{*}}{G^{*}} \text { if } G<G^{*}
\end{array},\right.
$$

\footnotetext{
${ }^{1}$ Firms with one worker or similarly tiny ones would blur the analysis of segregation and therefore, throughout the paper, the analysis is restricted to establishments with at least 5 workers.

${ }^{2}$ We use the uniform distribution to generate random numbers that sort workers, before they are matched to the original array of employers (keeping the original number of positions available in each employer). Using a random number generator, we guarantee that the reallocation does not follow a systematic pattern. The procedure used also guarantees that the data set has exactly the original structure (establishment size and gender composition of the workforce).

${ }^{3}$ Taking 100 samples of 10 percent from the original data.
} 
where $\hat{G} \in[-1,1]$. If actual segregation exceeds random segregation $\left(G>G^{*}\right)$, then $\hat{G}$ quantifies excess segregation over that dictated by chance, expressed in percentage of the maximum segregation that could occur $\left(1-G^{*}\right)$. When $G<G^{*}$, we face a situation in which there is excess impartiality in the distribution of gender across establishments, that is, not even random allocation would be able to obtain that balance in the distribution of individuals. As this index assesses random deviation, its interpretation is not based on the quota of minorities nor on the size of the units. However, as the size of units increases, the modified segregation index, $\hat{G}$, tends toward the value of the original index, $G$. The same procedure applies to the dissimilarity index.

\begin{tabular}{|l||c|c|c|c|c|c|}
\hline \multicolumn{1}{|c||}{} & \multicolumn{2}{c|}{ Total Segregation } & \multicolumn{2}{c|}{ Random Segregation } & \multicolumn{2}{c|}{ Systematic Segregation } \\
\hline & dissimilarity & Gini & dissimilarity & Gini & dissimilarity & Gini \\
\hline \hline 1985 & $0.553(0.016)$ & $0.732(0.016)$ & $0.121(0.005)$ & $0.190(0.007)$ & $0.492(0.017)$ & $0.670(0.019)$ \\
1987 & $0.552(0.016)$ & $0.737(0.014)$ & $0.123(0.005)$ & $0.193(0.006)$ & $0.489(0.018)$ & $0.674(0.016)$ \\
1989 & $0.556(0.016)$ & $0.739(0.012)$ & $0.126(0.004)$ & $0.197(0.006)$ & $0.491(0.017)$ & $0.674(0.014)$ \\
1991 & $0.553(0.014)$ & $0.736(0.011)$ & $0.129(0.004)$ & $0.200(0.005)$ & $0.487(0.015)$ & $0.670(0.014)$ \\
1993 & $0.548(0.012)$ & $0.733(0.012)$ & $0.135(0.004)$ & $0.210(0.005)$ & $0.478(0.012)$ & $0.662(0.014)$ \\
1995 & $0.559(0.012)$ & $0.741(0.009)$ & $0.138(0.006)$ & $0.214(0.005)$ & $0.488(0.012)$ & $0.670(0.011)$ \\
1997 & $0.564(0.009)$ & $0.744(0.010)$ & $0.141(0.004)$ & $0.218(0.005)$ & $0.493(0.010)$ & $0.672(0.013)$ \\
1999 & $0.563(0.009)$ & $0.742(0.007)$ & $0.144(0.004)$ & $0.223(0.006)$ & $0.489(0.010)$ & $0.668(0.009)$ \\
\hline
\end{tabular}

Table 1: Gender segregation at the establishment level. Note: Bootstrap standard errors in parenthesis. Source: Computations based on Portugal, MSST (1985 to 1999).

Gender segregation across establishments in the Portuguese labour market is high and has been relatively stable between 1985 and 1999 (see table 1). We observe a slight increase in the random segregation, which can be explained by the change in the dimension of establishments ${ }^{4}$ and in the female participation in the labour market.

Systematic segregation, when measured by the Gini coefficient, has been stable around $67 \%$ during this period. The dissimilarity index reveals as well stability, around the value $49 \%$. This suggests a very high level of segregation when compared to the USA manufacturing, since Carrington and Troske (1998) have reported values of $33 \%$ and $45 \%$, respectively for the dissimilarity and the Gini in-

\footnotetext{
${ }^{4}$ The average establishment size in the population under study decreased from 31 to 22 workers over the period.
} 
dex. The values for Portugal are however remarkably in line with those presented for the Korean economy by Yoon et al (2003).

\section{The impact of gender segregation on wages}

To analyse the impact of gender segregation at the establishment level on wages, consider regressions of the type:

$$
W_{g i}=\beta_{g} X_{g i}+\eta_{g i}
$$

where subscript $g=(m, f)$ indicates the gender, $W_{g i}$ is the log wage of worker $i$, $X_{g i}$ denotes a set of individual and job related characteristics, which includes the proportion of females in the establishment; $\beta_{g}$ denotes the regression coefficients and $\eta_{g i}$ is a random error term assumed to satisfy the usual properties. Hourly wages were computed as monthly wages divided by the number of hours worked. Tables 4 and 5 in appendix list all the variables included and their descriptive statistics.

From OLS estimation of equations (4) it follows that:

$$
\bar{W}_{m}-\bar{W}_{f}=\left(\bar{X}_{m}-\bar{X}_{f}\right) \hat{\beta}_{m}+\left(\hat{\beta}_{m}-\hat{\beta}_{f}\right) \bar{X}_{f}
$$

which is the Oaxaca (1973) male-based decomposition. The first term on the right hand side indicates the portion of the wage gap attributable to differences between sexes in the mean values of productive and job related characteristics (i.e. differences in endowments); the second term represents the portion attributable to differences in prices of those characteristics (often referred to as discrimination). The idea of the first term is to value the difference in endowments at the wage rate that would prevail in the economy in the absence of discrimination (the nondiscriminatory wage structure, following the reasoning by Becker (1971)). Oaxaca suggested using alternatively male or female wages as that reference wage distribution, to define a range within which the values of the components would fall.

Cotton (1988) and Neumark (1988) choose instead the computation of a specific point within that range, by considering the non-discriminatory wage structure $\left(\hat{\beta}^{*}\right)$ 
as the weighted average of the female and male wage structures, with weights equal to their employment shares. The wage decomposition would therefore be defined as follows:

$$
\bar{W}_{m}-\bar{W}_{f}=\left(\bar{X}_{m}-\bar{X}_{f}\right) \hat{\beta}^{*}+\left(\hat{\beta}_{m}-\hat{\beta}^{*}\right) \bar{X}_{m}+\left(\hat{\beta}^{*}-\hat{\beta}_{f}\right) \bar{X}_{f}
$$

Differing from Oaxaca's proposal, the last two terms measure the male advantage and the female disadvantage in coefficients (i.e. the extent to which the returns to productive and other characteristics differ from the non-discriminatory returns). These two terms are then used as measures of the extent of labour market discrimination.

It therefore follows that the contribution of the proportion of female workers at the establishment level $(\mathrm{P})$ to the gender gap is given, under the Oaxaca method, by

$$
\left(\bar{P}_{m}-\bar{P}_{f}\right) \hat{\beta}_{m P}+\left(\hat{\beta}_{m P}-\hat{\beta}_{f P}\right) \bar{P}_{f}
$$

or by

$$
\left(\bar{P}_{m}-\bar{P}_{f}\right) \hat{\beta}^{*}+\left(\hat{\beta}_{m P}-\hat{\beta}^{*}\right) \bar{P}_{m}+\left(\hat{\beta}^{*}-\hat{\beta}_{f P}\right) \bar{P}_{f}
$$

under the Cotton-Neumark approach.

\subsection{Higher concentration of women in the establishment: lower wages for women, but higher for men}

The proportion of females in the establishment workforce has a negative impact on females' wages, with the coefficient being statistically different from zero in every year. Conversely, the higher the proportion of females in the establishment, the higher males' wages (except in 1999) (see tables 6 and 7 in appendix). This is a striking result, since the previous available evidence had revealed that the femaleness of the establishment depressed the wages of both men and women (see Carrington and Troske (1998) or Reilly and Wirjanto (1999)).

The taste-based discrimination and the quality-sorting theories reach different

predictions regarding wage gaps. According to the sorting theory, the wages of 
different groups of workers within a firm will be positively correlated. The discrimination theory, on the other hand, allows for the wages of men working with women to be higher than the wages of other men, to compensate them for the "disutility" of having female co-workers.

The evidence that a higher proportion of females in the establishment lowers wages for women but raises wages for men would therefore lend support to discrimination type of models, but not to sorting theories. It should however be pointed out that a test of this theory along the gender dimension is a narrow angle to view such theories.

\subsection{Segregation and the wage gap}

The contribution of the concentration of females at the establishment level to the gender wage differential is quite significant, varying from 11\% in 1985 and 1995 to $25 \%$ in 1999 (see the last column in table 2).

The role of prices has been prominent (see table 3). The Oaxaca methodology indicates that, concerning the proportion of females at the establishment level, the contribution of the endowment component is negative (except in 1999). In fact, given that the share of females has a positive impact on males wages (the reference wage distribution considered) and that women on average work in establishments with a higher proportion of females, the endowment component would raise females wages, reducing the gender wage gap. However, this is offset by the effect of differences in prices (i.e. coefficients) associated with the femaleness of the establishment (precisely because they are positive for men and negative for women, as previously reported). This price component accounts for $15 \%$ of the observed gap in 1985 and $21 \%$ in 1999, fluctuating during the period in-between.

The decomposition based on the Cotton-Neumark methodology reveals that, for the group of all the variables, differences in endowments, the male advantage and the female disadvantage contribute positively to the observed gender gap, which is in line with the results of Gyimah-Brempong et al (1992). The contribution of the female disadvantage is larger than the contribution of the male advantage. 


\begin{tabular}{|r||c|c|r|r|r|r|r|r|}
\hline \multicolumn{1}{|c||}{ Method. } & \multicolumn{2}{c|}{ Oaxaca (1973) } & \multicolumn{3}{c|}{ Cotton (1988), Neumark (1988) } & \\
\hline & endow. & prices & total & endow. & male adv. & fem. dis. & total & Pf/gap \\
\hline \hline 1985 & & & & & & & & \\
all var. & 0.1108 & 0.1465 & 0.2573 & 0.1112 & 0.0465 & 0.0997 & 0.2574 & \\
$\mathrm{Pf}$ & -0.0108 & 0.0389 & 0.0281 & -0.0028 & 0.0044 & 0.0264 & 0.0281 & 10.9 \\
1987 & & & & & & & & \\
all var. & 0.0944 & 0.1566 & 0.2510 & 0.0974 & 0.0486 & 0.1049 & 0.2510 & \\
$\mathrm{Pf}$ & -0.0132 & 0.0524 & 0.0391 & -0.0021 & 0.0061 & 0.0351 & 0.0391 & 15.6 \\
1989 & & & & & & & & \\
all var. & 0.0911 & 0.1787 & 0.2698 & 0.0992 & 0.0544 & 0.1162 & 0.2698 & \\
$\mathrm{Pf}$ & -0.0113 & 0.0789 & 0.0675 & 0.0063 & 0.0099 & 0.0513 & 0.0675 & 25.0 \\
1991 & & & & & & & & \\
all var. & 0.0952 & 0.1942 & 0.2894 & 0.1054 & 0.0617 & 0.1224 & 0.2894 & \\
$\mathrm{Pf}$ & -0.017 & 0.0838 & 0.0668 & 0.0027 & 0.0114 & 0.0528 & 0.0668 & 23.1 \\
1993 & & & & & & & & \\
all var. & 0.0911 & 0.1958 & 0.2869 & 0.1012 & 0.0643 & 0.1214 & 0.2869 & \\
$\mathrm{Pf}$ & -0.0102 & 0.0782 & 0.0681 & 0.0085 & 0.0110 & 0.0485 & 0.0681 & 23.7 \\
1995 & & & & & & & & \\
all var. & 0.1013 & 0.1631 & 0.2644 & 0.1047 & 0.0619 & 0.0979 & 0.2644 & \\
$\mathrm{Pf}$ & -0.0108 & 0.0389 & 0.0281 & -0.0037 & 0.0079 & 0.0238 & 0.0281 & 10.6 \\
1997 & & & & & & & & \\
all var. & 0.0943 & 0.1615 & 0.2558 & 0.0986 & 0.0619 & 0.0953 & 0.2558 & \\
$\mathrm{Pf}$ & -0.0059 & 0.0479 & 0.0420 & 0.0064 & 0.0073 & 0.0283 & 0.0420 & 16.4 \\
1999 & & & & & & & & \\
all var. & 0.0944 & 0.1641 & 0.2585 & 0.0990 & 0.0642 & 0.0952 & 0.2585 & \\
$\mathrm{Pf}$ & 0.0051 & 0.0542 & 0.0593 & 0.0193 & 0.0086 & 0.0314 & 0.0593 & 22.9 \\
\hline
\end{tabular}

Table 2: Male/female log-Wage decompositions. Source: Computations based on Portugal, MSST (1985 to 1999).

With respect to the proportion of females in the establishment, most of the observed gender gap is due to the female disadvantage component, rather than to the male advantage or to differences in endowments, whose contributions to the gap are fairly low. Indeed, female underpayment accounts for $10 \%$ to $19 \%$ of the gender pay gap, whereas male overpayment accounts for $2 \%$ to $4 \%$ of that gap. This finding is at odds with the results of Rilley and Wirjanto (1999), who found a negative contribution of the female disadvantage, suggesting that the impact of the femaleness of the establishment to the observed gender wage gap operated mainly through males' wage advantage.

In synthesis, for the Portuguese case, segregation remained at stable levels from 1985 to 1999, but nevertheless the degree of femaleness of the establishment 


\begin{tabular}{|r||r|r|r|r|r|r|r|r|r|r|}
\hline \multicolumn{1}{|c||}{} & \multicolumn{4}{c|}{ Oaxaca (1973) } & \multicolumn{5}{c|}{ Cot ton (1988) and Neumark (1988) } \\
\hline \multicolumn{1}{|c||}{} & all variables & \multicolumn{1}{c|}{ prop. females } & \multicolumn{3}{c|}{ all variables } & \multicolumn{3}{c|}{ prop. females } \\
\hline & end. & prices & end. & prices & end. & male ad. & fem. dis. & end. & male ad. & fem. dis. \\
\hline \hline 1985 & 43.1 & 56.9 & -4.2 & 15.1 & 43.2 & 18.1 & 38.7 & -1.1 & 1.7 & 10.3 \\
1987 & 37.6 & 62.4 & -5.3 & 20.9 & 38.8 & 19.4 & 41.8 & -0.8 & 2.4 & 14.0 \\
1989 & 33.8 & 66.2 & -4.2 & 29.2 & 36.8 & 20.2 & 43.1 & 2.3 & 3.7 & 19.0 \\
1991 & 32.9 & 67.1 & -5.9 & 29.0 & 36.4 & 21.3 & 42.3 & 0.9 & 3.9 & 18.2 \\
1993 & 31.8 & 68.2 & -3.6 & 27.3 & 35.3 & 22.4 & 42.3 & 3.0 & 3.8 & 16.9 \\
1995 & 38.3 & 61.7 & -4.1 & 14.7 & 39.6 & 23.4 & 37.0 & -1.4 & 2.2 & 9.0 \\
1997 & 36.9 & 63.1 & -2.3 & 18.7 & 38.5 & 24.2 & 37.3 & 2.5 & 2.9 & 11.1 \\
1999 & 36.5 & 63.5 & 2.0 & 21.0 & 38.3 & 24.8 & 36.8 & 7.5 & 3.3 & 12.1 \\
\hline
\end{tabular}

Table 3: Contributions to the observed gender wage gap (\%). Source: Computations based on Portugal, MSST (1985 to 1999).

tended to become more relevant accounting for wage differences across gender, mainly through its price component.

\section{Conclusion}

This paper analysed gender segregation at the establishment level over fifteen years in Portugal, and its impact on wages and the gender wage gap. A large employer-employee matched data set has been used.

Results point to the existence of a remarkable level of systematic gender segregation at the establishment level, much higher than previously reported for the USA.

A higher proportion of females in the establishment lowers females' wages and, on the contrary, it raises males' wages. The latter is a striking outcome, which contrasts with the evidence available for other countries and lends support to the taste-based model of employer behaviour. Furthermore, the gender composition of the workforce within the establishments accounted for $11 \%$ of the observed gender wage gap in 1985 and $23 \%$ in 1999, fluctuating in-between. Most of the gap associated with the composition of the labour force can be attributed to the wage premium/penalty resulting form the femaleness of the establishment. These values seem particularly high and show that gender segregation of the workforce at the establishment level must be taken into account when analysing the gender 
wage gap and deciding on policy measures.

\section{References}

Becker, Gary S. (1971). The Economics of Discrimination. Chicago: University of Chicago Press.

Buckley, John E. (1971). Pay differences between men and women in the same job, Monthly Labor Review, 64(11), 36-39.

Carrington, William J. And Kenneth R. Troske (1995). Gender segregation in small firms, Journal of Human Resources, 30(3), 503-533.

Carrington, William J. and Kenneth R. Troske (1997). On measuring segregation in samples with small units, Journal of Business and Economic Statistics, 15(4), 402-409.

Carrington, William J. and Kenneth R. Troske (1998). Sex segregation in the U.S. manufacturing, Industrial and Labor Relations Review, 51(3), 445464.

Cotton, Jeremiah (1988). On the decomposition of wage differentials, Review of Economics and Statistics, 70(2), 236-243.

Groshen , Erica L. (1991). The structure of the female/male wage differential: is it who you are, what you do, or where you work? Journal of Human Resources, 26 (3), 457-472.

Gyimah-Brempong, Kwabena, Rudy Fichtenbaum and Gregory Willis (1992) The effects of College education on the male-female wage differential, Southern Economic Journal, 58(3), 790-804.

Hutchens, Robert (2001). Numerical measures of segregation: desirable properties and their implications, Mathematical Social Sciences, 42(1), 13-29.

Kremer, Michael (1993). The O-ring theory of economic development, Quarterly Journal of Economics, 108(3), 551-575. 
Kiker, B. F. and Maria C. Santos (1991). Human capital and earnings in Portugal, Economics of Education Review, 10(3), 187-203.

McNulty, Donald J. (1967). Differences in pay between men and women workers, Monthly Labor Review, 90(12), 40-43.

Neumark, David (1988). Employers' discriminatory behavior and the estimation of wage discrimination, Journal of Human Resources, 23(3), 279-295.

OAXacA, Ronald L. (1973). Male-female wage differentials in urban labor markets, International Economic Review, 14, 693-709.

Pfeffer, Jeffrey and Alison Davis-Blake (1987). The effect of the proportion of women on salaries: the case of College administrators, Industrial and Labor Relations Review, 31(1), 1-24.

Portugal. Ministério da Segurança Social e do Trabalho (19851999). Quadros de Pessoal. Data in magnetic media.

Reilly, Kevin T. and Tony S. Wirjanto (1999). Does more mean less? The male/female wage gap and the proportion of females at the establishment level, Canadian Journal of Economics, 32(4), 906-929.

Vieira, José A. Cabral (1999). The evolution of wage structures in Portugal 1982-1992, Ph.D. Thesis, Amsterdam: Tinbergen Institute.

Yoon, Soohyun, Kenneth R. Troske and Peter Mueser (2003). Changes in gender segregation and women's wages in Korea. Mimeo. University of Missouri-Columbia. 


\begin{tabular}{|c|c|c|c|c|c|c|c|c|}
\hline & 1985 & 1987 & 1989 & 1991 & 1993 & 1995 & 1997 & 1999 \\
\hline Ln hourly wage & 5.2596 & 5.5933 & 5.8110 & 6.1595 & 6.3603 & 6.4971 & 6.5818 & 6.7216 \\
\hline Education & 5.5132 & 5.6484 & 5.9063 & 6.1435 & 6.3539 & 6.6805 & 7.0088 & 7.3542 \\
\hline Experience & 26.208 & 26.127 & 25.507 & 25.387 & 25.294 & 24.810 & 24.298 & 24.204 \\
\hline Experience squared & 848.27 & 840.94 & 810.48 & 807.32 & 801.6 & 777.17 & 756.13 & 753.48 \\
\hline Tenure & 10.006 & 10.1162 & 9.4890 & 9.2806 & 9.1149 & 8.9454 & 8.5275 & 8.4567 \\
\hline Tenure squared & 178.10 & 183.91 & 175.58 & 175.83 & 170.14 & 165.72 & 158.41 & 158.44 \\
\hline Ln firm size & 4.6677 & 4.5950 & 4.4681 & 4.3857 & 4.2385 & 4.0938 & 4.0590 & 4.0027 \\
\hline Lisbon & 0.4251 & 0.4103 & 0.4007 & 0.3997 & 0.3948 & 0.3805 & 0.3798 & 0.3804 \\
\hline $\begin{array}{l}\text { Proportion of females } \\
\text { Occupations: }\end{array}$ & 0.1997 & 0.2052 & 0.2145 & 0.2228 & 0.2295 & 0.2363 & 0.2404 & 0.2463 \\
\hline Managers, higher clericals & 0.0111 & 0.0103 & 0.0113 & 0.0119 & 0.0113 & 0.0311 & 0.0357 & 0.0401 \\
\hline Clerical staff & 0.0895 & 0.0883 & 0.0936 & 0.0982 & 0.1007 & 0.1161 & 0.1152 & 0.1269 \\
\hline Commercial staff & 0.1357 & 0.1329 & 0.1274 & 0.1248 & 0.1244 & 0.1329 & 0.1248 & 0.1231 \\
\hline Security and other services & 0.0585 & 0.0588 & 0.056 & 0.0568 & 0.0586 & 0.0701 & 0.0715 & 0.0697 \\
\hline Farmers, agricult. workers & 0.0024 & 0.002 & 0.0026 & 0.0023 & 0.0021 & 0.0029 & 0.0035 & 0.0033 \\
\hline Production workers (group 1) & 0.2931 & 0.2892 & 0.2861 & 0.2921 & 0.2868 & 0.2933 & 0.2953 & 0.2923 \\
\hline Production workers (group 2) & 0.1738 & 0.1718 & 0.1629 & 0.1651 & 0.1603 & 0.1793 & 0.1812 & 0.1759 \\
\hline Production workers (group 3) & 0.2118 & 0.2215 & 0.2353 & 0.2201 & 0.2286 & 0.1367 & 0.1363 & 0.1336 \\
\hline Indus & & & & & & & & \\
\hline Textiles, clothing, footwear & 0.0919 & 0.0949 & 0.0938 & 0.0898 & 0.0848 & 0.083 & 0.078 & 0.0708 \\
\hline Wood, cork & 0.0461 & 0.046 & 0.0448 & 0.0408 & 0.0407 & 0.0476 & 0.0465 & 0.0441 \\
\hline Paper, print, publish. & 0.0272 & 0.0271 & 0.0266 & 0.0263 & 0.0249 & 0.0251 & 0.0238 & 0.023 \\
\hline Chemical products & 0.0480 & 0.0468 & 0.0438 & 0.0368 & 0.0346 & 0.0285 & 0.0255 & 0.0262 \\
\hline Non-metal minerals & 0.0430 & 0.0406 & 0.0387 & 0.0398 & 0.0382 & 0.0346 & 0.0325 & 0.0336 \\
\hline Primary metals & 0.0210 & 0.0203 & 0.0176 & 0.0144 & 0.013 & 0.0088 & 0.0081 & 0.0077 \\
\hline Machinery, equipment & 0.1315 & 0.1239 & 0.124 & 0.1176 & 0.119 & 0.1075 & 0.1125 & 0.1102 \\
\hline Elect., gas, water & 0.0214 & 0.0214 & 0.0157 & 0.0181 & 0.0173 & 0.0168 & 0.0161 & 0.0141 \\
\hline Construction & 0.1247 & 0.1257 & 0.1363 & 0.1449 & 0.1488 & 0.1574 & 0.1665 & 0.1634 \\
\hline Wholesale & 0.0903 & 0.0904 & 0.0893 & 0.0924 & 0.0922 & 0.0865 & 0.0835 & 0.0847 \\
\hline Retail & 0.0474 & 0.0491 & 0.054 & 0.0563 & 0.0592 & 0.0874 & 0.0884 & 0.0902 \\
\hline Rest., cafes, hotels & 0.0309 & 0.0321 & 0.0332 & 0.0336 & 0.0351 & 0.0399 & 0.0389 & 0.0387 \\
\hline Transportation & 0.1083 & 0.1117 & 0.1014 & 0.1096 & 0.106 & 0.1002 & 0.0971 & 0.0982 \\
\hline Banking, insurance & 0.0555 & 0.0541 & 0.0601 & 0.0584 & 0.0601 & 0.0595 & 0.0523 & 0.0484 \\
\hline Servi & 0.0176 & 0.0182 & 0.0219 & 0.0261 & 0.0282 & 0.0045 & 0.0048 & 0.0056 \\
\hline Social, personal serv. & 0.0440 & 0.0463 & 0.0484 & 0.0480 & 0.0506 & 0.0675 & 0.0832 & 0.1008 \\
\hline
\end{tabular}

Table 4: Sample mean values (males). Source: Computations based on Portugal, MSST (1985 to 1999). 


\begin{tabular}{|c|c|c|c|c|c|c|c|c|}
\hline & 1985 & 1987 & 1989 & 1991 & 1993 & 1995 & 1997 & 1999 \\
\hline Ln hourly wage & 5.0022 & 5.3423 & 5.5412 & 5.8701 & 6.0735 & 6.2327 & 6.3260 & 6.4631 \\
\hline Education & 5.4763 & 5.7060 & 6.0359 & 6.3121 & 6.5439 & 7.0174 & 7.3776 & 7.7936 \\
\hline Experience & 22.168 & 22.272 & 21.626 & 21.267 & 21.240 & 21.278 & 21.125 & 21.118 \\
\hline Experience squared & 627.35 & 631.66 & 603.7 & 588.88 & 588.39 & 592.58 & 592.64 & 597.43 \\
\hline Tenure & 8.9576 & 9.0402 & 8.3458 & 7.8066 & 7.5880 & 7.7406 & 7.4244 & 7.2951 \\
\hline Tenure squared & 136.07 & 143.12 & 135.83 & 129.95 & 124.24 & 127.21 & 123.15 & 122.81 \\
\hline Ln firm size & 4.6199 & 4.5449 & 4.4241 & 4.3596 & 4.2646 & 4.1835 & 4.1423 & 4.1082 \\
\hline Lisbon & 0.4018 & 0.3948 & 0.3790 & 0.3733 & 0.3709 & 0.3621 & 0.3588 & 0.3702 \\
\hline $\begin{array}{l}\text { Proportion of females } \\
\text { Occupations: }\end{array}$ & 0.5639 & 0.5767 & 0.5956 & 0.6082 & 0.6185 & 0.6341 & 0.6455 & 0.6505 \\
\hline Managers, higher clericals & 0.0127 & 0.0139 & 0.0166 & 0.0171 & 0.0202 & 0.0305 & 0.0351 & 0.0405 \\
\hline Clerical staff & 0.0677 & 0.0704 & 0.0742 & 0.0793 & 0.0814 & 0.0718 & 0.0721 & 0.0814 \\
\hline Commercial staff & 0.2124 & 0.2019 & 0.1968 & 0.1894 & 0.1852 & 0.2145 & 0.2067 & 0.2125 \\
\hline Security and other services & 0.0768 & 0.0817 & 0.0825 & 0.0861 & 0.0967 & 0.1400 & 0.1624 & 0.1713 \\
\hline Farmers, agricult. workers & 0.0016 & 0.0012 & 0.0023 & 0.0018 & 0.0014 & 0.0016 & 0.0021 & 0.0018 \\
\hline Production workers (group 1) & 0.2469 & 0.2506 & 0.2541 & 0.2649 & 0.2512 & 0.2427 & 0.2388 & 0.2219 \\
\hline Production workers (group 2) & 0.1249 & 0.1143 & 0.0954 & 0.0812 & 0.0707 & 0.0943 & 0.0797 & 0.0697 \\
\hline Production workers (group 3) & 0.2507 & 0.2575 & 0.2681 & 0.2685 & 0.2824 & 0.1886 & 0.1871 & 0.1848 \\
\hline Industries: & & & & & & & & \\
\hline Textiles, clothing, footwear & 0.3288 & 0.3287 & 0.3279 & 0.3210 & 0.3017 & 0.2858 & 0.2633 & 0.2366 \\
\hline Wood, cork & 0.027 & 0.0248 & 0.0234 & 0.0224 & 0.0222 & 0.0261 & 0.0258 & 0.0252 \\
\hline Paper, print, publish. & 0.0216 & 0.0217 & 0.02 & 0.018 & 0.0172 & 0.0178 & 0.0159 & 0.0157 \\
\hline Chemical products & 0.0396 & 0.0363 & 0.0318 & 0.0275 & 0.0248 & 0.0198 & 0.0167 & 0.0177 \\
\hline Non-metal minerals & 0.0248 & 0.0233 & 0.0222 & 0.0245 & 0.024 & 0.0238 & 0.0223 & 0.0226 \\
\hline Primary metals & 0.0049 & 0.0041 & 0.0035 & 0.0028 & 0.0024 & 0.0016 & 0.0014 & 0.0016 \\
\hline Machinery, equipment & 0.0689 & 0.0657 & 0.0600 & 0.0633 & 0.0627 & 0.0674 & 0.0684 & 0.0716 \\
\hline Elect., gas, water & 0.0068 & 0.0069 & 0.0045 & 0.0050 & 0.0046 & 0.0042 & 0.0043 & 0.0037 \\
\hline Construction & 0.0129 & 0.0117 & 0.0141 & 0.0161 & 0.0162 & 0.0157 & 0.0167 & 0.0171 \\
\hline Wholesale & 0.0687 & 0.0654 & 0.0643 & 0.0648 & 0.0647 & 0.0594 & 0.0579 & 0.0587 \\
\hline Retail & 0.0627 & 0.0651 & 0.0679 & 0.0716 & 0.0785 & 0.0948 & 0.1043 & 0.1118 \\
\hline Rest., cafes, hotels & 0.0534 & 0.0542 & 0.0563 & 0.0574 & 0.063 & 0.0715 & 0.0710 & 0.0684 \\
\hline Transportation & 0.0585 & 0.0582 & 0.0534 & 0.0524 & 0.0489 & 0.0433 & 0.0407 & 0.0388 \\
\hline Banking, insurance & 0.0421 & 0.0402 & 0.0447 & 0.0419 & 0.0436 & 0.0440 & 0.0396 & 0.0398 \\
\hline Services to firms & 0.0139 & 0.0162 & 0.0210 & 0.0256 & 0.0284 & 0.0046 & 0.0048 & 0.0056 \\
\hline Social, personal : & 0.0916 & 0.1112 & 0.1238 & 0.1275 & 0.1441 & 0.1683 & 0.1984 & 0.2217 \\
\hline
\end{tabular}

Table 5: Sample mean values (females). Source: Computations based on Portugal, MSST (1985 to 1999). 


\begin{tabular}{|l||rr|rr|rr|rr|}
\hline \multicolumn{1}{|c||}{} & \multicolumn{2}{c|}{1985} & \multicolumn{2}{c|}{1987} & \multicolumn{2}{c|}{1989} & \multicolumn{2}{c|}{1991} \\
\hline \multicolumn{1}{|c||}{ coeff. } & t-value & coeff. & t-value & coeff. & t-value & coeff. & t-value \\
\hline \hline Intercept & 4.4763 & 1010.9 & 4.7145 & 1056.4 & 4.9234 & 1042.7 & 5.3015 & 1066.8 \\
Education & 0.0506 & 290.6 & 0.0552 & 305.2 & 0.0623 & 331.8 & 0.0656 & 328.1 \\
Experience & 0.0268 & 197.6 & 0.0287 & 204.3 & 0.0296 & 207.3 & 0.0281 & 182.3 \\
Experience sq./100 & -0.0353 & -162.0 & -0.0374 & -165.0 & -0.0383 & -164.0 & -0.0362 & -142.6 \\
Tenure/10 & 0.1036 & 86.4 & 0.1047 & 85.5 & 0.1033 & 81.0 & 0.0982 & 68.8 \\
Tenure squared/100 & -0.0129 & -36.3 & -0.0122 & -33.3 & -0.0118 & -30.0 & -0.0103 & -23.3 \\
Ln firm size & 0.0575 & 245.2 & 0.0604 & 250.2 & 0.0551 & 216.9 & 0.0543 & 188.4 \\
Region: Lisbon & 0.0726 & 98.2 & 0.0686 & 89.4 & 0.0763 & 93.7 & 0.0985 & 109.9 \\
Proportion of females & 0.0296 & 13.7 & 0.0356 & 16.1 & 0.0297 & 13.2 & 0.0441 & 18.1 \\
Occupation(9 categories) & yes & yes & yes & yes & yes & yes & yes & yes \\
Industry (17 categories) & yes & yes & yes & yes & yes & yes & yes & yes \\
\hline Adjusted R2 & 0.6234 & & 0.6373 & & 0.5995 & & 0.5596 & \\
F-statistic & 49927 & & 51571 & & 44192 & & 37456 & \\
Sigma & 0.3104 & & 0.3174 & & 0.3424 & & 0.3780 & \\
Observ. & 862137 & & 860395 & & 889362 & & 885135 & \\
\hline
\end{tabular}

\begin{tabular}{|l||rr|rr|rr|rr|}
\hline \multicolumn{1}{|c||}{} & \multicolumn{2}{c|}{1993} & \multicolumn{2}{c|}{1995} & \multicolumn{2}{c|}{1997} & \multicolumn{2}{c|}{1999} \\
\hline & coeff. & t-value & coeff. & t-value & coeff. & t-value & coeff. & t-value \\
\hline \hline Intercept & 5.4926 & 1058.2 & 5.9543 & 1088.1 & 6.0823 & 1139.7 & 6.2650 & 1220.0 \\
Education & 0.0682 & 331.8 & 0.0474 & 216.9 & 0.0456 & 223.3 & 0.0459 & 243.8 \\
Experience & 0.0279 & 172.7 & 0.0272 & 176.1 & 0.0269 & 182.8 & 0.0254 & 193.0 \\
Experience sq./100 & -0.0350 & -130.6 & -0.0363 & -141.1 & -0.0357 & -143.7 & -0.0336 & -151.5 \\
Tenure/10 & 0.1015 & 64.6 & 0.1052 & 67.9 & 0.1304 & 89.0 & 0.1420 & 105.2 \\
Tenure squared/100 & -0.0134 & -27.3 & -0.0125 & -25.8 & -0.0188 & -41.2 & -0.0203 & -48.1 \\
Ln firm size & 0.0554 & 185.4 & 0.0570 & 191.8 & 0.0584 & 212.7 & 0.0569 & 215.4 \\
Region: Lisbon & 0.1104 & 116.3 & 0.1037 & 112.3 & 0.0923 & 102.8 & 0.0934 & 112.8 \\
Proportion of females & 0.0262 & 10.4 & 0.0344 & 14.7 & 0.0147 & 6.6 & -0.0127 & -6.4 \\
Occupation(9 categories) & yes & yes & yes & yes & yes & yes & yes & yes \\
Industry (17 categories) & yes & yes & yes & yes & yes & yes & yes & yes \\
\hline Adjusted R2 & 0.5444 & & 0.6041 & & 0.5951 & & 0.6343 & \\
F-statistic & 34186 & & 41458 & & 42779 & & 48645 & \\
Sigma & 0.3947 & & 0.3787 & & 0.3771 & & 0.3526 & \\
Observ. & 868326 & & 859522 & & 923256 & & 947959 & \\
\hline
\end{tabular}

Table 6: Ordinary least squares Regressions (males). Source: Computations based on Portugal, MSST (1985 to 1999). 


\begin{tabular}{|l||rr|rr|rr|rr|}
\hline \multicolumn{1}{|c||}{} & \multicolumn{2}{c|}{1985} & \multicolumn{2}{c|}{1987} & \multicolumn{2}{c|}{1989} & \multicolumn{2}{c|}{1991} \\
\hline \multicolumn{1}{|c||}{ coeff. } & t-value & coeff. & t-value & coeff. & t-value & coeff. & t-value \\
\hline \hline Intercept & 4.5373 & 517.8 & 4.7177 & 598.4 & 4.9534 & 642.1 & 5.2926 & 701.9 \\
Education & 0.0475 & 178.1 & 0.0564 & 203.0 & 0.0610 & 229.3 & 0.0662 & 235.6 \\
Experience & 0.0155 & 81.8 & 0.0166 & 87.7 & 0.0175 & 99.5 & 0.0161 & 89.4 \\
Experience sq./100 & -0.0192 & -59.6 & -0.0199 & -61.7 & -0.0202 & -65.2 & -0.0180 & -54.8 \\
Tenure/10 & 0.1209 & 72.0 & 0.1213 & 72.8 & 0.1186 & 71.3 & 0.1169 & 64.8 \\
Tenure squared/100 & -0.0216 & -38.8 & -0.0199 & -35.5 & -0.0195 & -32.0 & -0.0173 & -26.2 \\
Ln firm size & 0.0458 & 138.6 & 0.0486 & 147.3 & 0.0444 & 133.3 & 0.0443 & 126.4 \\
Region: Lisbon & 0.0764 & 70.4 & 0.0679 & 62.3 & 0.0660 & 61.0 & 0.0795 & 69.4 \\
Proportion of females & -0.0393 & -17.6 & -0.0552 & -24.3 & -0.1027 & -45.1 & -0.0936 & -38.6 \\
Occupation(9 categories) & yes & yes & yes & yes & yes & yes & yes & yes \\
Industry (17 categories) & yes & yes & yes & yes & yes & yes & yes & yes \\
\hline Adjusted R2 & 0.6594 & & 0.6498 & & 0.6355 & & 0.5864 & \\
F-statistic & 26711 & & 27544 & & 27130 & & 23685 & \\
i & 0.2730 & & 0.2827 & & 0.2979 & & 0.3319 & \\
Observ. & 402523 & & 424697 & & 477440 & & 507748 & \\
\hline
\end{tabular}

\begin{tabular}{|l||rr|rr|rr|rr|}
\hline \multicolumn{1}{|c||}{} & \multicolumn{2}{|c|}{1993} & \multicolumn{2}{c|}{1995} & \multicolumn{2}{c|}{1997} & \multicolumn{2}{c|}{1999} \\
\hline & coeff. & t-value & coeff. & t-value & coeff. & t-value & coeff. & t-value \\
\hline \hline Intercept & 5.4427 & 675.2 & 5.8800 & 756.4 & 6.0455 & 834.8 & 6.2469 & 931.2 \\
Education & 0.0710 & 246.4 & 0.0434 & 170.1 & 0.0411 & 177.0 & 0.0423 & 213.5 \\
Experience & 0.0166 & 87.2 & 0.0176 & 98.3 & 0.0183 & 109.6 & 0.0169 & 126.2 \\
Experience sq./100 & -0.0182 & -52.2 & -0.0228 & -68.3 & -0.0243 & -78.6 & -0.0215 & -88.8 \\
Tenure/10 & 0.1297 & 63.3 & 0.1284 & 67.8 & 0.1368 & 79.6 & 0.1482 & 105.2 \\
Tenure squared/100 & -0.0228 & -30.9 & -0.0221 & -33.5 & -0.0236 & -39.9 & -0.0254 & -52.7 \\
Ln firm size & 0.0473 & 135.3 & 0.0548 & 164.7 & 0.0532 & 174.7 & 0.0440 & 172.4 \\
Region: Lisbon & 0.0927 & 75.8 & 0.0769 & 68.4 & 0.0715 & 66.8 & 0.0637 & 72.5 \\
Proportion of females & -0.1003 & -38.7 & -0.0283 & -12.0 & -0.0596 & -26.8 & -0.0960 & -50.7 \\
Occupation(9 categories) & yes & yes & yes & yes & yes & yes & yes & yes \\
Industry (17 categories) & yes & yes & yes & yes & yes & yes & yes & yes \\
\hline Adjusted R2 & 0.5631 & & 0.6317 & & 0.6118 & & 0.6833 & \\
F-statistic & 22708 & & 29610 & & 31207 & & 37252 & \\
Sigma & 0.3573 & & 0.3392 & & 0.3383 & & 0.2937 & \\
Observ. & 524732 & & 562909 & & 634009 & & 675553 & \\
\hline
\end{tabular}

Table 7: Ordinary Least squares Regressions (Females). Source: Computations based on Portugal, MSST (1985 to 1999). 


\section{IZA Discussion Papers}

\begin{tabular}{|c|c|c|c|c|}
\hline No. & Author(s) & Title & Area & Date \\
\hline 774 & $\begin{array}{l}\text { A. Constant } \\
\text { D. S. Massey }\end{array}$ & $\begin{array}{l}\text { Labor Market Segmentation and the Earnings of } \\
\text { German Guestworkers }\end{array}$ & 1 & 05/03 \\
\hline 775 & $\begin{array}{l}\text { J. J. Heckman } \\
\text { L. J. Lochner } \\
\text { P. E. Todd }\end{array}$ & Fifty Years of Mincer Earnings Regressions & 5 & $05 / 03$ \\
\hline 776 & $\begin{array}{l}\text { L. Arranz-Aperte } \\
\text { A. Heshmati }\end{array}$ & $\begin{array}{l}\text { Determinants of Profit Sharing in the Finnish } \\
\text { Corporate Sector }\end{array}$ & 2 & $05 / 03$ \\
\hline 777 & $\begin{array}{l}\text { A. Falk } \\
\text { M. Kosfeld }\end{array}$ & $\begin{array}{l}\text { It's all about Connections: Evidence on Network } \\
\text { Formation }\end{array}$ & 6 & $05 / 03$ \\
\hline 778 & F. Galindo-Rueda & $\begin{array}{l}\text { Employer Learning and Schooling-Related } \\
\text { Statistical Discrimination in Britain }\end{array}$ & 5 & $05 / 03$ \\
\hline 779 & M. Biewen & $\begin{array}{l}\text { Who Are the Chronic Poor? Evidence on the } \\
\text { Extent and the Composition of Chronic Poverty } \\
\text { in Germany }\end{array}$ & 1 & $05 / 03$ \\
\hline 780 & $\begin{array}{l}\text { A. Engellandt } \\
\text { R. T. Riphahn }\end{array}$ & Temporary Contracts and Employee Effort & 1 & $05 / 03$ \\
\hline 781 & $\begin{array}{l}\text { J. H. Abbring } \\
\text { J.R. Campbell }\end{array}$ & $\begin{array}{l}\text { A Structural Empirical Model of Firm Growth, } \\
\text { Learning, and Survival }\end{array}$ & 5 & $05 / 03$ \\
\hline 782 & $\begin{array}{l}\text { M. Güell } \\
\text { B. Petrongolo }\end{array}$ & $\begin{array}{l}\text { How Binding Are Legal Limits? Transitions from } \\
\text { Temporary to Permanent Work in Spain }\end{array}$ & 1 & $05 / 03$ \\
\hline 783 & $\begin{array}{l}\text { B. T. Hirsch } \\
\text { E. J. Schumacher }\end{array}$ & $\begin{array}{l}\text { Match Bias in Wage Gap Estimates Due to } \\
\text { Earnings Imputation }\end{array}$ & 5 & $05 / 03$ \\
\hline 784 & $\begin{array}{l}\text { O. Pierrard } \\
\text { H. R. Sneessens }\end{array}$ & $\begin{array}{l}\text { Low-Skilled Unemployment, Biased } \\
\text { Technological Shocks and Job Competition }\end{array}$ & 2 & $05 / 03$ \\
\hline 785 & R. Almeida & $\begin{array}{l}\text { The Effects of Foreign Owned Firms on the } \\
\text { Labor Market }\end{array}$ & 2 & $05 / 03$ \\
\hline 786 & $\begin{array}{l}\text { P. Mueser } \\
\text { K. R. Troske } \\
\text { A. Gorislavsky }\end{array}$ & $\begin{array}{l}\text { Using State Administrative Data to Measure } \\
\text { Program Performance }\end{array}$ & 6 & $05 / 03$ \\
\hline 787 & $\begin{array}{l}\text { P. Garibaldi } \\
\text { L. Pacelli } \\
\text { A. Borgarello }\end{array}$ & $\begin{array}{l}\text { Employment Protection Legislation and the Size } \\
\text { of Firms }\end{array}$ & 3 & $05 / 03$ \\
\hline 788 & $\begin{array}{l}\text { F. Büchel } \\
\text { J. R. Frick }\end{array}$ & $\begin{array}{l}\text { Immigrants in the UK and in West Germany - } \\
\text { Relative Income Position, Income Portfolio, and } \\
\text { Redistribution Effects }\end{array}$ & 1 & $06 / 03$ \\
\hline 789 & $\begin{array}{l}\text { J. A. Cabral Vieira } \\
\text { A. R. Cardoso } \\
\text { M. Portela }\end{array}$ & $\begin{array}{l}\text { Recruitment and Pay at the Establishment } \\
\text { Level: Gender Segregation and the Wage Gap } \\
\text { in Portugal }\end{array}$ & 5 & $06 / 03$ \\
\hline
\end{tabular}

An updated list of IZA Discussion Papers is available on the center's homepage www.iza.org. 